\title{
ELEVATED TRIGLYCERIDE GLUCOSE INDEX IS RELATED TO THE PRESENCE OF HEART FAILURE
}

\section{YÜKSEK TRIGLISERID GLUKOZ INDEKSI KALP YETMEZLIĞi VARLIĞIYLA ILIŞKILIDIR}

\author{
Sara ÇETIN ŞANLIALP' (D), Gökay NAR² (D), Mehmet Güven GÜNVER ${ }^{3}$ \\ ${ }^{1}$ Servergazi State Hospital, Cardiology Clinic, Denizli, Turkey \\ ${ }^{2}$ Pamukkale University, Faculty of Medicine, Department of Cardiology, Denizli, Turkey \\ ${ }^{3}$ Istanbul University, Istanbul Faculty of Medicine, Department of Biostatistics, Istanbul, Turkey
}

ORCID IDs of the authors: S.Ç.Ş. 0000-0001-9328-9127; G.N. 0000-0001-6159-7785; M.G.G. 0000-0002-4628-8391

Cite this article as: Cetin Sanlialp S, Nar G, Gunver MG. Elevated triglyceride glucose index is related to the presence of heart failure. J Ist Faculty Med 2022;85(1):51-8. doi: 10.26650/IUITFD.898541

\section{ABSTRACT}

Objective: Previous studies have shown a significant association between insulin resistance (IR) measured by using different methods and heart failure (HF). In recent years, the triglyceride glucose (TyG) index has been used to measure $I R$, and there are several reports showing that the TyG index indicates conditions such as metabolic syndrome (MetS) and atherosclerotic process. However, there is no study investigating the association of the TyG index with HF. Therefore, we aimed to evaluate the role of the TyG index in HF presence and its relationship with HF severity in this study.

Materials and Methods: Sixty-nine subjects matched for age and gender were analyzed retrospectively. The TyG index was used to measure IR and was calculated by the formula Ln [fasting triglycerides $(\mathrm{mg} / \mathrm{dl}) \times$ fasting glucose $(\mathrm{mg} / \mathrm{dl}) / 2$ ]. The severity of HF was assessed by New York Heart Association (NYHA) functional class, left ventricular ejection fraction (LVEF) and N- terminal prohormone brain natriuretic peptide (NT-proBNP).

Results: HF patients had higher TyG index (9.11 00.59 vs. 8.55 $\pm 0.55 ; p<0.001$ ) but there was no correlation between TyG index with HF severity identified by NYHA functional class, LVEF and NT-proBNP. The ROC curve showed the cut-off point of the TyG index in determining HF as 9.19 with $71 \%$ sensitivity and $51 \%$ specificity (AUC:0.745, $p<0.001$ ).

Conclusion: TyG index may be a useful marker for diagnosis of $\mathrm{HF}$, but is not correlated with HF severity.

Keywords: Heart failure, insulin resistance, triglyceride glucose index

\begin{abstract}
ÖZET
Amaç: Önceki çalışmalar, farklı yöntemler kullanılarak ölçülen insülin direnci (IR) ile kalp yetmezliği (KY) arasında önemli bir ilişki olduğunu göstermiş̧tir. Son yıllarda, trigliserid glikoz (TyG) indeksi IR'ni ölçmek için kullanılmaktadır ve TyG indeksinin, metabolik sendrom (MetS) ve aterosklerotik süreç gibi durumları gösterdiğine dair birkaç rapor vardır. Ancak TyG indeksinin KY ile ilişkisini araştıran herhangi bir çalışma yoktur. Bu nedenle, biz bu çalışmada TyG indeksinin $K Y$ varlığındaki rolünü ve $K Y$ şiddeti ile ilişkisini değerlendirmeyi amaçladık.
\end{abstract}

Gereç ve Yöntem: Yaş ve cinsiyet uyumlu 69 hasta geriye dönük olarak incelendi. IR'ni ölçmek için TyG indeksi kullanıldı ve Ln [açlık trigliseridleri $(\mathrm{mg} / \mathrm{dl}) \times$ açlık glikozu $(\mathrm{mg} / \mathrm{dl}) / 2$ ] formülüyle hesaplandı. KY'nin şiddeti, New York Kalp Derneği (NYHA) fonksiyonel sınıfı, sol ventriküler ejeksiyon fraksiyonu (LVEF) ve $\mathrm{N}$-terminal prohormon beyin natriüretik peptidi (NT-proBNP) ile değerlendirildi.

Bulgular: KY hastaları daha yüksek TyG indeksine sahipti $(9,11 \pm 0,59$ 'a karşı 8,55 $\pm 0,55 ; p<0,001)$. Ancak NYHA fonksiyonel sınıfı, LVEF, NT-proBNP ile tanımlanan KY şiddeti ile TyG indeksi arasında herhangi bir korelasyon yoktu. ROC eğrisi, KY'nin belirlenmesinde TyG indeksinin kesme noktasını \%71 duyarlılık ve \%51 özgüllük ile 9,19 olarak gösterdi (AUC:0,745, p<0,001).

Sonuç: TyG indeksi, KY tanısı için yararlı bir belirteç olabilir ancak KY ciddiyeti ile ilişkili değildir.

Anahtar Kelimeler: Kalp yetmezliği, insülin direnci, trigliserid glikoz indeksi

Corresponding author/iletişim kurulacak yazar: saracetin@hotmail.com.tr

Submitted/Başvuru: 17.03.2021 • Revision Requested/Revizyon Talebi: 15.04.2021 • Last Revision Received/Son Revizyon: 16.04.2021 • Accepted/Kabul: 28.04.2021 • Published Online/Online Yayın: 22.11 .2021 


\section{INTRODUCTION}

Heart failure (HF) is one of the leading causes of mortality and morbidity worldwide. Although the pathophysiological mechanisms underlying HF are still not fully understood, previous animal and human studies have shown a significant relation between $\mathrm{HF}$ and insulin resistance (IR) (1). Currently, real-life data studies have reported that HF is associated with hyperglycemia or chronic hyperglycemic conditions such as $I R$, diabetes and that the incidence of $\mathrm{HF}$ is higher in patients with these conditions (2).

The triglyceride glucose (TyG) index has been derived from fasting triglyceride and glucose, and several studies have shown the relationship between the TyG index with hypertension, diabetes, metabolic syndrome (MetS), arterial stiffness and coronary artery calcification. In addition, the TyG index may be an indicator for determining the presence and severity of coronary artery disease, carotid atherosclerosis and ischemic stroke according to the recent study results (3-5). However, no study investigating the relationship between the TyG index and HF has yet been reported in the literature. Hence, we aimed to evaluate the role of the TyG index in patients with $\mathrm{HF}$ in this study.

\section{MATERIALS AND METHODS}

\section{Study population}

In this study, age and gender matched 69 subjects who were admitted to our cardiology outpatient clinic were analyzed retrospectively. Acute coronary syndrome, acute myocarditis/pericarditis, malignancy, acute and chronic infections, autoimmune diseases, severe hematological disorders, systemic inflammatory diseases, chronic renal failure (glomerular filtration rate calculated by Cockcroft-Gault formula $<50 \mathrm{~mL} / \mathrm{min} / 1.73 \mathrm{~m}^{2}$ ), severe liver failure and pregnancy were defined as exclusion criteria. The subjects aged $18-90$ years with a diagnosis of $\mathrm{HF}$ for at least 6 months and left ventricular ejection fraction (LVEF) $<40 \%$ were included in the patient group $(n=34)$. The New York Heart Association (NYHA) functional classification was determined by cardiologists who were blind to the patients' clinical data. The subjects aged 18-90 with LVEF $>50 \%$, but no known history of heart disease or clinical findings were included in the control group $(n=35)$. This study was approved by our institutional ethical committee in accordance with the Declaration of Helsinki (2021/01, protocol no:020-4331).

\section{Data collection and definitions}

Previously recorded data such as demographic, medical history, medications and the laboratory findings including fasting blood glucose (FBG), renal function tests, lipid parameters, complete blood counts and serum $\mathrm{N}$ - terminal prohormone brain natriuretic peptide (NT-proBNP) concentrations were re-analyzed. The TyG index was cal- culated by the formula Ln [fasting triglycerides ( $\mathrm{mg} / \mathrm{dl}$ ) xfasting glucose (mg/dl)/2] (6). LVEF calculated by modified biplanar Simpson method of the study population was scanned retrospectively.

Hypertension was defined in accordance with the criteria of World Health Organization (WHO) (7). The diagnosis of diabetes was based on the American Diabetes Association criteria (8). National Cholesterol Education Programme guidelines were used for the definition of dyslipidemia (9).

\section{Statistical analysis}

Statistical analysis was performed using SPSS version 21.0 software (SPSS, Inc., Chicago, III., USA). In expressing the values, number (percentage) for categorical variables and mean \pm standard deviation for continuous variables were used. Kolmogorov-Smirnov test was done to determine the normal distribution. Student's t-test or chi-square test was performed to compare variables between groups where appropriate. The relationship between TyG index and other variables was evaluated using Pearson's correlation analysis. In the advanced stage, the association between the TyG index with variables, including HF severity indicators, was assessed by multiple logistic regression after the adjustment for any potential confounding. Curve analysis receiver operating characteristics analysis (ROC) was used to predict the ability of the TyG index to detect the presence of HF.

\section{RESULTS}

The baseline characteristics of the study population are presented in Table 1. The incidences of comorbidity such as hypertension, diabetes, hyperlipidemia and vital signs including systolic blood pressure, diastolic blood pressure, and heart rate did not differ between the groups. Laboratory parameters including FBG, $\mathrm{HbA} 1 \mathrm{c}$, sodium, creatinine, triglyceride, HDL-C, white blood cells (WBC), albumin and NT-proBNP showed significant differences in the groups $(p<0.05)$. However, there was no significant difference in total cholesterol, LDL-C and hemoglobin levels. The TyG index was higher in HF patients compared to controls ( $9.11 \pm 0.59$ vs $8.55 \pm 0.55 ; p<0.001)$. The ROC curve generated from the TyG index resulted in the area under the curve (AUC) of 0.745 to indicate HF presence and and the cut-off point calculated based on this curve was 9.19 with $71 \%$ sensitivity and $51 \%$ specificity (Figure 1).

In Pearson's correlation analysis, a significant relationship was found between the TyG index with systolic blood pressure, total cholesterol, creatinine, as well as its components FBG and triglycerides (Table 2). However, the TyG index was not significantly correlated with body mass index, diastolic blood pressure, heart rate, LVEF, hemoglobin A1c (HbA1c), LDL-C, HDL-C, hemoglobin, WBC, albumin and, NYHA functional class, LVEF or NT-proBNP 
Table 1: Baseline characteristics and medications of study population

\begin{tabular}{|c|c|c|c|}
\hline Variables & Subjects with HF $(n=34)$ & Subjects without HF $(n=35)$ & $p$ \\
\hline Mean age (years) & $64.17 \pm 9.57$ & $62.57 \pm 9.22$ & 0.481 \\
\hline Males, n (\%) & $16(47)$ & $16(46)$ & 0.911 \\
\hline Body mass index $\left(\mathrm{kg} / \mathrm{m}^{2}\right)$ & $28.06 \pm 4.98$ & $28.42 \pm 4.55$ & 0.751 \\
\hline Hypertension, n (\%) & $15(44)$ & $13(37)$ & 0.555 \\
\hline Diabetes, n (\%) & $14(41)$ & $9(26)$ & 0.173 \\
\hline Hyperlipidemia, n (\%) & $12(35)$ & $6(17)$ & 0.086 \\
\hline Current smoking, n (\%) & $3(9)$ & $7(20)$ & 0.187 \\
\hline Systolic blood pressure $(\mathrm{mmHg})$ & $119.00 \pm 13.24$ & $120.43 \pm 14.67$ & 0.672 \\
\hline Diastolic blood pressure $(\mathrm{mmHg})$ & $75.94 \pm 10.35$ & $74.29 \pm 8.23$ & 0.463 \\
\hline Heart rate (beats/minute) & $75.21 \pm 13.33$ & $69.83 \pm 11.62$ & 0.078 \\
\hline LVEF (\%) & $26.60 \pm 4.55$ & $59.26 \pm 3.58$ & $<0.001$ \\
\hline Atrial fibrillation, $\mathrm{n}(\%)$ & $10(29)$ & - & - \\
\hline NYHA III-IV, n (\%) & $20(58)$ & - & - \\
\hline Ischemic etiology, n (\%) & $19(56)$ & - & - \\
\hline ACEI/ARB, n (\%) & $25(74)$ & $12(34)$ & 0.001 \\
\hline Beta-blockers, n (\%) & $31(91)$ & $3(9)$ & $<0.001$ \\
\hline Statins, n (\%) & $12(35)$ & $2(6)$ & 0.002 \\
\hline Antiplatelets, n (\%) & $32(94)$ & $9(26)$ & $<0.001$ \\
\hline Diuretics, n (\%) & $23(67)$ & & \\
\hline Digitalis, n (\%) & $9(26)$ & & \\
\hline
\end{tabular}

LVEF: left ventricular ejection fraction, NYHA: New York Heart Association, ACEl: Angiotensin-converting enzyme inhibitor, ARB: Angiotensin receptor blocker, HF: heart failure

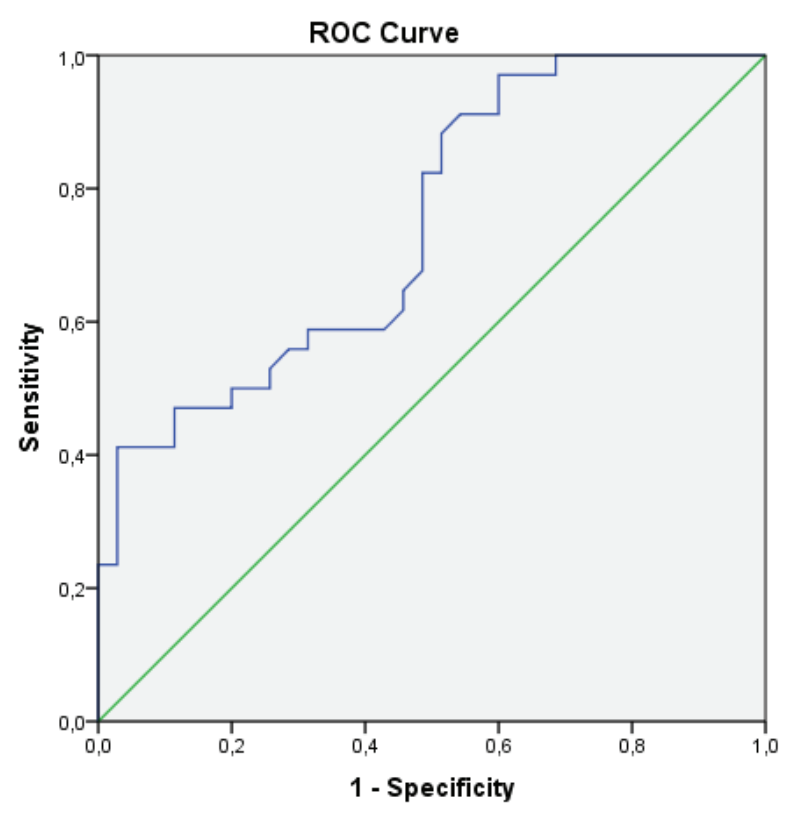

Diagonal segments are produced by ties.

Figure 1: Receiver operator characteristic curve (ROC) of TyG index in predicting the presence of heart failure TyG index: triglyceride glucose index used in predicting HF severity and prognosis (Table 2, Figure 2). In addition, TyG index did not differ significantly in HF subgroups divided as ischemic and non-ischemic (Figure 3). In the multiple logistic regression analysis, it was found that none of the variables used in the model was independently associated with the TyG index, but the combination of these variables could strongly indicate a high TyG index as presented in Table 3 (95\% $\mathrm{Cl}: 3.366-8.157 ; \mathrm{p}<0.001)$.

\section{DISCUSSION}

In this study, we found that the patients with HF had a higher TyG index, but did not correlate with parameters indicating HF severity, including LVEF, NT-proBNP, and NYHA functional class. After adjusting the confounding factors by multiple logistic regression analysis, we observed that none of the clinical variables alone was associated with the TyG index, but their combination strongly indicated the high TyG index.

IR is defined as the impairment of cells' ability to respond to the action of insulin in the transport of glucose from the bloodstream to target tissues (10). IR is related to dyslipidemic conditions and patients with IR are typ- 
Table 2: The laboratory data of study population

\begin{tabular}{lccc}
\hline Variables & Subjects with HF $(\mathbf{n}=\mathbf{3 4})$ & Subjects without HF $(\mathbf{n}=\mathbf{3 5})$ & $\mathbf{p}$ \\
FBG $(\mathrm{mg} / \mathrm{dl})$ & $117.02 \pm 28.56$ & $97.26 \pm 12.59$ & $<0.001$ \\
HbA1c & $6.45 \pm 1.05$ & $5.59 \pm 0.80$ & $<0.001$ \\
Creatinine $(\mathrm{mg} / \mathrm{dl})$ & $0.96 \pm 0.17$ & $0.75 \pm 0.13$ & $<0.001$ \\
Sodium $(\mathrm{mEg} / \mathrm{L})$ & $139.14 \pm 3.54$ & $140.63 \pm 1.97$ & 0.003 \\
T-chol $(\mathrm{mg} / \mathrm{dl})$ & $189.71 \pm 46.63$ & $193.20 \pm 41.54$ & 0.743 \\
TG $(\mathrm{mg} / \mathrm{dl})$ & $167.35 \pm 78.06$ & $119.69 \pm 55.32$ & $<0.001$ \\
LDL-C $(\mathrm{mg} / \mathrm{dl})$ & $109.97 \pm 30.98$ & $116.48 \pm 33.98$ & 0.408 \\
HDL-C $(\mathrm{mg} / \mathrm{dl})$ & $40.67 \pm 7.48$ & $52.57 \pm 13.38$ & $<0.001$ \\
Hemoglobin $(\mathrm{g} / \mathrm{dl})$ & $13.61 \pm 1.29$ & $14.16 \pm 1.25$ & 0.076 \\
WBC $(\mathrm{cell} / \mathrm{s} / \mathrm{LL})$ & $9.23 \pm 2.00$ & $6.98 \pm 1.54$ & $<0.001$ \\
Albumin $(\mathrm{g} / \mathrm{dL})$ & $4.25 \pm 0.26$ & $4.57 \pm 0.23$ & $<0.001$ \\
NT-proBNP $(\mathrm{pg} / \mathrm{ml})$ & $613.71 \pm 433.70$ & $97.32 \pm 49.78$ & $<0.001$ \\
TyG index & $9.11 \pm 0.59$ & $8.55 \pm 0.55$ & $<0.001$ \\
\hline
\end{tabular}

FBG: fasting blood glucose, HbA1c: hemoglobin A1c, T-chol: total cholesterol, TG: triglycerides, LDL-C: low-density lipoprotein cholesterol, HDL-C: high-density lipoprotein cholesterol, WBC: white blood cells, NT-proBNP: N-terminal prohormone brain natriuretic peptide, TyG index: triglyceride glucose index, HF: heart failure
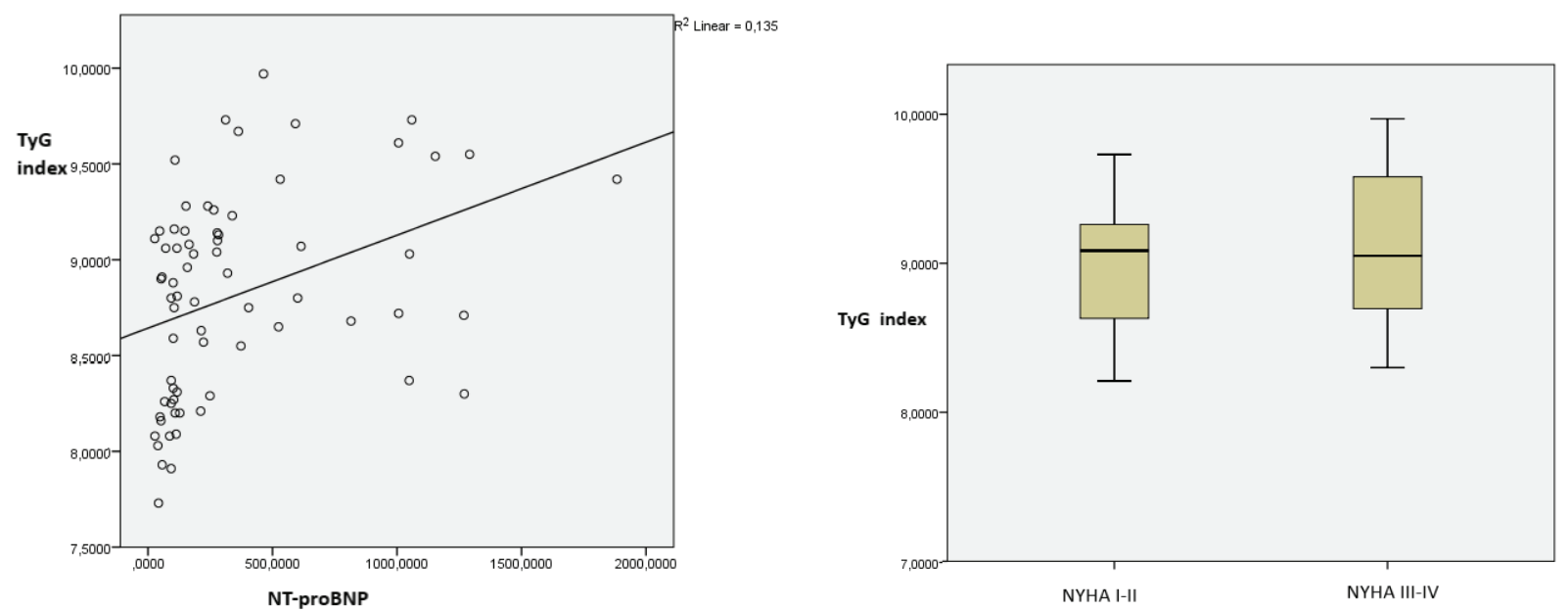

Figure 2: The relationship between TyG index with NT-proBNP and NYHA functional class TyG index: triglyceride glucose index, NT-proBNP: N- terminal pro hormone brain natriuretic peptide, NYHA: New York Heart Association

ically characterized by high triglycerides, small dense LDL particles and low HDL-C levels. Also, triglycerides and triglyceride-rich lipoproteins play a major role in atherosclerosis, which is the main etiologic factor of HF by reducing of endothelial function, increasing of proinflammatory cytokines expression, inducing of monocyte-platelet activation and raising of fibrinogen levels $(11,12)$. However, there is increasing evidence of the direct effects of IR on heart failure itself (13). The major responsible mechanisms are listed as follows: (i)
TNF- $\alpha$ is a pre-inflammatory cytokine associated with $\mathrm{HF}$ and it has been reported that TNF- $\alpha$ may affect the glucose metabolism. Indeed, a study showed that patients with IR had higher TNF- $\alpha$ levels compared to insulin-sensitive patients; (ii) In IR, both plasma and cardiac free fatty acids (FFA) and triglycerides concentrations increase and their accumulation in myocardial cells may result in apoptosis and fibrosis due to lipotoxic effects. Moreover, FFA may trigger IR by activation of Toll-like Receptor 4 and the innate immune response; (iii) Activa- 


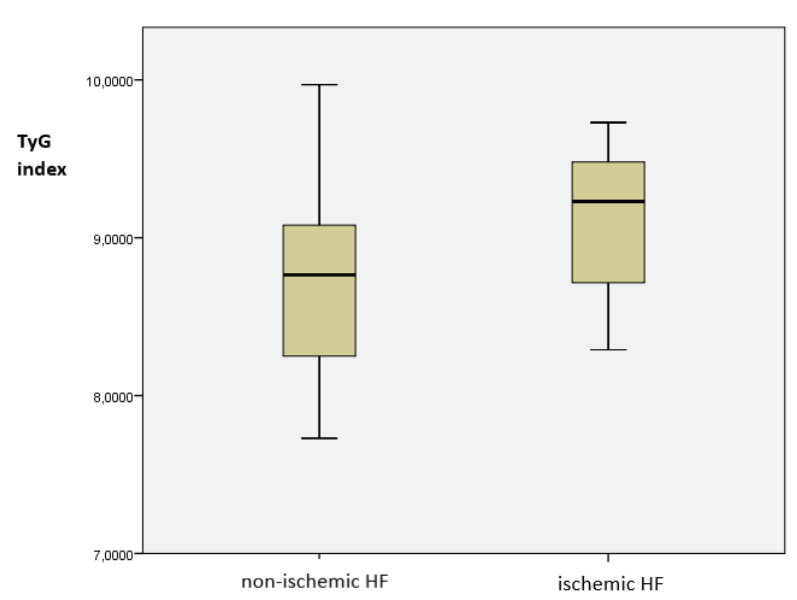

Figure 3: The TyG index levels according to underlying etiology in heart failure

TyG index: triglyceride glucose index, HF: heart failure

tion of the renin-angiotensin II-aldosterone (RAAS) and sympathetic nervous system have been associated with impairment of glucose metabolism, and the interaction between IR and RAAS may contribute to HF through ab-
Table 3: Correlation between the TyG index and clinical variables

\begin{tabular}{lll}
\hline Variables & $\mathbf{r}$ & $\mathbf{p}$ \\
Systolic blood pressure & 0.364 & 0.034 \\
FBG & 0.553 & $<0.001$ \\
Creatinine & 0.420 & 0.010 \\
T-chol & 0.345 & 0.045 \\
TG & 0.567 & $<0.001$ \\
\hline
\end{tabular}

FPG: fasting blood glucose, T-chol: total cholesterol, TG: triglycerides, TyG index: triglyceride glucose index

normal aldosterone release by triggering of TNF- $\alpha$ and IL-6 (iv) IR causes to endothelial dysfunction by reducing $\mathrm{NO}$ release in endothelial cells, and this may result in hypoxia and inhibition of angiogenesis, leading to myocardial cell apoptosis (v) The other culprit mechanisms are mitochondrial dysfunction and endoplasmic reticulum stress. Hyperglycemia may trigger inflammatory responses through mitochondrial dysfunction in oxidative stress, resulting in cell apoptosis. In addition, it has been

Table 4: Multiple logistic regression analysis for TyG index

\begin{tabular}{|c|c|c|c|c|c|c|c|}
\hline \multirow{2}{*}{ Model } & \multicolumn{2}{|c|}{$\begin{array}{l}\text { Unstandardized } \\
\text { coefficients }\end{array}$} & \multirow{2}{*}{$\begin{array}{c}\text { Standardized } \\
\text { coefficients } \\
\text { Beta }\end{array}$} & \multirow{2}{*}{$\mathbf{t}$} & \multirow{2}{*}{$p$} & \multicolumn{2}{|c|}{$\begin{array}{l}95.0 \% \text { Confidence } \\
\text { interval for B }\end{array}$} \\
\hline & B & Std.Error & & & & $\begin{array}{l}\text { Lower } \\
\text { bound }\end{array}$ & $\begin{array}{l}\text { Upper } \\
\text { bound }\end{array}$ \\
\hline Constant & 5.761 & 1.148 & - & 5.018 & $<0.001$ & 3.366 & 8.157 \\
\hline LVEF & 0.004 & 0.011 & 0.128 & 0.359 & 0.721 & -0.018 & 0.026 \\
\hline FBG & 0.007 & 0.003 & 0.401 & 2.075 & 0.051 & 0.000 & 0.013 \\
\hline T-chol & 0.002 & 0.003 & 0.194 & 0.685 & 0.501 & -0.004 & 0.008 \\
\hline TG & 0.002 & 0.001 & 0.346 & 1.952 & 0.065 & 0.000 & 0.004 \\
\hline Systolic blood pressure & 0.004 & 0.008 & 0.101 & 0.463 & 0.648 & -0.013 & 0.020 \\
\hline Diastolic blood pressure & -0.004 & 0.010 & -0.080 & -0.353 & 0.727 & -0.025 & 0.018 \\
\hline $\mathrm{HbA1c}$ & 0.074 & 0.099 & 0.161 & 0.745 & 0.465 & -0.133 & 0.280 \\
\hline Creatinine & 0.022 & 0.504 & 0.078 & 0.441 & 0.664 & -0.830 & 1.275 \\
\hline LDL-C & 0.001 & 0.004 & 0.038 & 0.158 & 0.876 & -0.007 & 0.008 \\
\hline HDL-C & 0.006 & 0.013 & 0.093 & 0.454 & 0.655 & -0.021 & 0.033 \\
\hline Hemoglobin & 0.044 & 0.068 & 0.118 & 0.647 & 0.525 & -0.098 & 0.185 \\
\hline NT-proBNP & 0.000 & 0.000 & -0.036 & -0.131 & 0.897 & -0.001 & 0.001 \\
\hline Ischemia & -0.095 & 0.202 & -0.100 & -0.471 & 0.643 & -0.517 & 0.327 \\
\hline NYHA III-IV & 0.165 & 0.238 & 0.172 & 0.694 & 0.496 & -0.331 & 0.661 \\
\hline
\end{tabular}

LVEF: left ventricular ejection fraction, FBG: fasting blood glucose, T-chol: total cholesterol, TG: triglycerides, HbA1c: hemoglobin A1c LDL-C: low-density lipoprotein cholesterol, HDL-C: high-density lipoprotein cholesterol, NT-proBNP: N- terminal prohormone brain natriuretic peptide, NYHA: New York Heart Association, TyG index: triglyceride glucose index 
reported that miR 19a-3p, 144-5p, miR-34a and miR-21 polymorphisms responsible for glycolipid metabolism disorders are associated with myocardial dysfunction $(11,14-16)$. Considering the effects of glycolipid disorders on HF, the TyG index derived from triglycerides, and glucose is likely to indicate the presence of HF.

In the first studies investigating the relationship between $\mathrm{HF}$ and hyperglycemia, IR was measured using the euglycemic-hyperglycemic clamp method, and one study showed impaired insulin-mediated glucose uptake into skeletal muscle and liver muscle tissue in HF patients (15). In later studies, IR was measured by non-invasive methods such as the homeostatic model assessment of insulin resistance (HOMA-IR) score. In a study using HOMA-IR, HF patients had a higher IR than healthy volunteers. Another study conducted with 12,606 subjects, Atherosclerosis Risk in Communities (ARIC) study, showed the relationship between HOMA-IR and increased risk of HF $(17,18)$. Unlike these studies, we used the TyG index for the first time to evaluate IR in HF patients and confirmed the relationship between HF presence and IR with a different method.

Several studies have reported the relationship between HF severity and IR. In a study, HF patients with IR had a worse 6-minute walking test than patients without IR (19). In another study, the relationship between insulin sensitivity and $\mathrm{HF}$ severity was evaluated with peak $\mathrm{VO}_{2}$, which is used to determine functional exercise capacity, and lower peak $\mathrm{VO}_{2}$ levels were observed in patients with reduced insulin sensitivity (20). However, we could not find any correlation between TyG index and HF severity in our study. In contrast to these studies, we used the NYHA functional classification, which is more subjective and based on patients' symptoms due to retrospective design. Also in these studies, the use of digoxin and diuretics, which improve functional capacity, was higher and the mean age was lower compared to our patients. In addition, the decrease in physiological functional capacity with aging may lead to defining the NYHA as class more exaggerated in our patients. Moreover, IR may reduce the glucose uptake into skeletal muscle, which may increase fatigue by reducing skeletal muscle strength, and this may be more pronounced in older ages. Finally, prolongation of $\mathrm{HF}$ exposure time may increase the severity of diastolic dysfunction in our patients, and it may contribute to progression of HF symptoms independently from IR (21).

The other parameter used for evaluation of HF severity was LVEF in this study. In addition, we investigated the importance of etiology in the TyG index, but we failed showing the correlation between the TyG index and these parameters. Indeed, one study did not show any relationship between IR with LVEF and HF etiology
(22). In another study, abnormalities in insulin metabolism were found to be similar in patients diagnosed with ischemic or dilated cardiomyopathy, and it has been claimed that IR may develop as a part of a neurohormonal and metabolic response in HF rather than atherosclerotic disease (15). In addition, there was no correlation between the TyG index and variables with confounding effects such as blood pressure, age, and body mass index in multiple logistic regression analysis in our study. The absence of any relationship between these parameters and IR in the study conducted by Suskin et al supports our study results (19). However, many mechanisms may be responsible for the relationship between $\mathrm{HF}$ and IR, and it is not clear which mechanism explains this relationship more, and in our study, multiple logistic regression analysis showed the interaction of many factors with each other for high TyG index in HF.

There are also studies investigating the relationship between IR and NT-proBNP levels in hyperglycemic patients. A study found lower BNP levels in HF patients with diabetes than in non-diabetic HF patients, and lower levels of NT-proBNP were associated with less HF symptoms and HF severity. The researchers explained this status as beta-adrenergic receptor antagonism may increase plasma BNP levels and its increased levels may lead to a decrease in IR $(19,23)$. In another study, there was an inverse association between NT-proBNP and HOMA-IR, and the insulin sensitivity index was an independent predictor of plasma NT-proBNP levels in HF patients. This has been associated with the lipolytic effects of BNP, and it has been hypothesized that decreased natriuretic peptide signals may cause IR and MetS by increasing lipid accumulation in adipose tissue and skeletal muscle (24). Unlike these studies, we could not find any association between the TyG index and NT-proBNP. The different result of our study at this point may be due to the heterogeneous distribution of comorbidities closely related to IR and MetS, such as hypertension, diabetes, hyperlipidemia or the differences in visceral fat accumulation or the intensive use of beta blockers.

There were some limitations to be addressed in our study. The study was a relatively small sample, and most patients were under HF treatment, which could affect glucose metabolism. HOMA-IR was not analyzed and compared with the TyG index as insulin levels could not be measured. Due to the lack of data, confounding factors such as exercise and diet habits, participation in a cardiac rehabilitation program, and cardiorespiratory fitness were not included in this study.

In conclusion, TyG index can be used for diagnosis in patients with HF symptoms, but not for HF severity. Howev- 
er, larger studies are needed to determine the relationship between TyG index and HF.

Ethics Committee Approval: This study was approved by the Non-Invasive Clinical Research Ethical Committee of the, Pamukkale University (Date: 05.01.2021 No: 01).

Peer Review: Externally peer-reviewed.

Author Contributions: Conception/Design of Study- S.Ç.Ş., G.N.; Data Acquisition- S.Ç.Ş., G.N.; Data Analysis/Interpretation- M.G.G.; Drafting Manuscript- S.Ç.Ş., G.N., M.G.G.; Critical Revision of Manuscript- S.Ç.S.., G.N., M.G.G.; Approval and Accountability- S.Ç.Ş., G.N., M.G.G.

Conflict of Interest: Authors declared no conflict of interest.

Financial Disclosure: Authors declared no financial support.

\section{REFERENCES}

1. Fu F, Zhao K, Li J, Xu J, Zhang Y, Liu C, et al. Direct Evidence that Myocardial Insulin Resistance following Myocardial Ischemia Contributes to Post-Ischemic Heart Failure. Sci Rep 2015;5:17927. [CrossRef]

2. Udell JA, Cavender MA, Bhatt DL, Chatterjee S, Farkouh ME, Scirica BM. Glucose lowering drugs or strategies and cardiovascular outcomes in patients with or at risk for type 2 diabetes: A meta-analysis of randomised controlled trials. Lancet Diabetes Endocrinol 2015;(3):356-366. [CrossRef]

3. Irace C, Carallo C, Scavelli FB, De Franceschi MS, Esposito T, Tripolino C, et al. Markers of insulin resistance and carotid atherosclerosis. A comparison of the homeostasis model assessment and triglyceride glucose index Int J Clin Pract 2013;67(7):665-72. [CrossRef]

4. Wang L, Cong H, Zhang J, Hu Y, Wei A, Zhang Y, et al. Triglyceride-glucose index predicts adverse cardiovascular events in patients with diabetes and acute coronary syndrome. Cardiovasc Diabetol 2020;19(1):80. [CrossRef]

5. da Silva A, Silva Caldas APS, Miranda HHH, Bersch-Ferreira AC, Ragne TC, Weber B, et al. Triglyceride-glucose index is associated with symptomatic coronary artery disease in patients in secondary care. Cardiovasc Diabetol 2019;18(1):89. [CrossRef]

6. Simental-Mendía LE, Rodríguez-Morán M, GuerreroRomero F. The product of fasting glucose and triglycerides as surrogate for identifying insulin resistance in apparently healthy subjects. Metab Syndr Relat Disord 2008;6(4):299304. [CrossRef]

7. Chalmers J, MacMahon S, Mancia G, Whitworth J, Beilin L, Hansson L, et al. 1999 World Health OrganizationInternational Society of Hypertension Guidelines for the management of hypertension. Guidelines sub-committee of the World Health Organization. Clin Exp Hypertens. 1999;21(5-6):1009-60. [CrossRef]

8. American Diabetes Association. 2. Classification and diagnosis of diabetes: Standards of Medical Care in Diabetes-2019. Diabetes Care 2019;42(Supplement 1):S1328. [CrossRef]
9. Executive summary of the Third Report of the National Cholesterol Education Program (NCEP) Expert Panel on Detection, Evaluation and Treatment of High Blood Cholesterol in Adults (Adult Treatment Panel III). JAMA 2001;285(19):2486-97. [CrossRef]

10. Reaven GM. Banting lecture 1988. Role of insulin resistance in human disease. Diabetes 1988;37(12):1595-607. [CrossRef]

11. Ormazabal V, Nair S, Elfeky O, Aguayo C, Salomon C, Zuñiga FA. Association between insulin resistance and the development of cardiovascular disease. Cardiovasc Diabetol 2018;17(1):122. [CrossRef]

12. Chapman MJ, Ginsberg HN, Amarenco $P$, Andreotti $F$, Borén J, Catapano AL, et al. European Atherosclerosis Society Consensus Panel. Triglyceride-rich lipoproteins and high-density lipoprotein cholesterol in patients at high risk of cardiovascular disease: evidence and guidance for management. Eur Heart J 2011;32(11):1345-61. [CrossRef]

13. Paolisso G, De Riu S, Marrazzo G, Verza M, Varricchio M, $D^{\prime}$ Onofrio $F$. Insulin resistance and hyperinsulinemia in patients with chronic congestive heart failure. Metabolism 1991;40(9):972-7. [CrossRef]

14. Aroor AR, Mandavia CH, Sowers JR. Insulin resistance and heart failure: molecular mechanisms. Heart Fail Clin 2012;8(4):609-17. [CrossRef]

15. Coats AJ, Anker SD. Insulin Resistance in Chronic Heart Failure. J Cardiovasc Pharmacol 2000;35(7):9-14. [CrossRef]

16. Marín-Royo G, Ortega-Hernández A, Martínez-Martínez E, Jurado-López R, Luaces M, Islas F, et al. The Impact of Cardiac Lipotoxicity on Cardiac Function and Mirnas Signature in Obese and Non-Obese Rats with Myocardial Infarction. Sci Rep 2019;9(1):444. [CrossRef]

17. Banerjee D, Biggs ML, Mercer L, Mukamal K, Kaplan $\mathrm{R}$, Barzilay $\mathrm{J}$ et al. Insulin resistance and risk of incident heart failure: Cardiovascular Health Study. Circ Heart Fail 2013;6(3):364-70. [CrossRef]

18. Vardeny O, Gupta DK, Claggett B, Burke S, Shah A, Loehr $\mathrm{L}$, et al. Insulin resistance and incident heart failure the ARIC study (Atherosclerosis Risk in Communities). JACC Heart Fail 2013;1(6):531-6. [CrossRef]

19. Suskin N, McKelvie RS, Burns RJ, Latini R, Pericak D, Probstfield J et al. Glucose and insulin abnormalities relate to functional capacity in patients with congestive heart failure. Eur Heart J 2000;21(16):1368-75. [CrossRef]

20. Swan JW, Anker SD, Walton C, Godsland IF, Clark AL, F. Leyva, et al. Insulin resistance in chronic heart failure: relation to severity and etiology of heart failure $\mathrm{J} \mathrm{Am} \mathrm{Coll}$ Cardiol 1997;(30):2:527-32. [CrossRef]

21. Anker SD, Swan JW, Volterrani M, Chua TP, Clark AL, Poole-Wilson PA, et al. The influence of muscle mass, strength, fatiguability and blood flow on exercise capacity in cachectic and non-cachetic patients with chronic heart failure. Eur Heart J 1997;18(2):259-69. [CrossRef]

22. ALZadjali MA, Godfrey V, Khan F, Choy AM, Doney AS, Wong $A K$, et al. Insulin resistance is highly prevalent and is associated with reduced exercise tolerance in nondiabetic patients with heart failure. J Am Coll Cardiol 2009;53(9):74753. [CrossRef] 
The triglyceride glucose index and heart failure

İstanbul Tıp Fakültesi Dergisi • J Ist Faculty Med 2022;85(1):51-8

23. Luchner A, Hense HW, Jougasaki M, Burnett JC Jr, Riegger GA, Schunkert H. Augmentation of natriuretic peptides by beta receptor antagonism: Evidence from a population based study. J Am Coll Cardiol 1998;32(7):1839-44. [CrossRef]
24. Chang HR, Hsieh JC, Hsu BG, Wang LY, Chen MYC, Wang $\mathrm{JH}$. Inverse Association of N-Terminal Pro-B-Type Natriuretic Peptide with Metabolic Syndrome in Patients with Congestive Heart Failure. PLoS ONE 2013;8(11):e79096. [CrossRef] 